\title{
Effects of wastewater treatment plant pollution on in-stream ecosystems functions in an agricultural watershed
}

\author{
José-Miguel Sánchez-Pérez ${ }^{1,2 *}$, Magali Gerino ${ }^{2}$, Sabine Sauvage $^{1,2}$, Pascal Dumas $^{1,2}$, \\ Éric Maneux ${ }^{1,2}$, Frédéric Julien ${ }^{2}$, Peter Winterton ${ }^{2}$ and Philippe Vervier ${ }^{1,2}$ \\ ${ }^{1}$ CNRS; ECOLAB (Laboratoire Écologie Fonctionnelle), École Nationale Supérieure Agronomique de Toulouse (ENSAT), \\ avenue de l'Agrobiopole, BP 32607, Auzeville Tolosane, 31326 Castanet Tolosan Cedex, France \\ 2 Université de Toulouse; INPT; UPS; ECOLAB (Laboratoire Écologie Fonctionnelle), 29 rue Jeanne Marvig, \\ 31029 Toulouse, France
}

Received 3rd October 2008; Accepted 12 April 2009

\begin{abstract}
We studied the effect of point-source and non-point-source pollution on the retention capacity of the stream and its link with the metabolic state (primary production and respiration) and invertebrates assemblages in a third order Mediterranean stream. Two experimental sites were chosen: one in the upper part of the catchment (Montégut site) characterized by low concentrations in nitrate and phosphate and one in the lower part of the catchment (Lézat site) characterized by high nitrate and phosphorus concentrations. Both experimental sites were located on reaches that included a Waste Water Treatment Plant (WWTP) point nutrient source allowing discussion of the relative effects of point-source and non-point-source nutrients loads on ecosystem function (respiration and uptake rates) and aquatic organism assemblages. $\mathrm{NH}_{4}^{+}-\mathrm{N}$, and $\mathrm{PO}_{4}^{3-}$-P uptake rates were determined using solute additions conducted at constant rates (short-term nutrient addition procedure) and $\mathrm{NO}_{3}^{-}-\mathrm{N}$ uptake rates were determined using instantaneous solute addition (slug addition procedure). Rates of gross primary production (GPP) and ecosystem respiration were determined using the open system, two-stations diurnal oxygen change method. Benthic invertebrate communities were investigated for species and functional feeding groups diversities measurements. Results show that autotrophy in the river results from nutrients of two distinct origins: point sources for phosphorus (urban area and WWTP) and non-point sources for nitrogen (agricultural zones) with local additions from WWTP inputs. Comparison between the two sites shows that the WWTP did not affect uptake rates, respiration or primary production of the ecosystem in the low-nutrient Montégut reach despite increase of invertebrates communities biomass density. Inputs from the WWTP, in the high nitrate and phosphate Lézat reach, increased respiration, lower benthic biomass and led to changes in the species composition and did not affect uptake rates.
\end{abstract}

Key words: Nutrient retention / benthic invertebrates / ecosystem respiration / rivers / wastewater treatment plant

\section{Introduction}

Nutrient loads in rivers are increasing due to human impact. The effects of nutrients excesses on stream metabolism and benthic invertebrate assemblages are relatively well documented but the effects of nutrient loads on instream uptake rates remain scarcely documented (e.g. Paul and Meyer, 2001). Nutrient uptakes rates are interesting indicators of the biogeochemical function of streams and the ability to quantify this uptake function (Turlan et al., 2007). Stream metabolism and stream communities affect the processes that influence nutrient uptake rates and thus

\footnotetext{
* Corresponding author: sanchez@cict.fr
}

nutrients loads, but it is not yet clear from the literature what are the respective contributions of these processes to nutrient uptake rate variations (Newbold et al., 1981).

One of the main difficulties in characterising the fundamental elements controlling biogeochemical function arises from the spatial and temporal variability of nutrient sources in stream ecosystems. Stream water quality depends not only on nutrient input from the catchments, but also on the capacity of streams to retain or remove part of the nutrient load. Nutrients (nitrogen and phosphorus) in runoff due to human activities can reach the stream either at specific locations (point sources) or via diffuse surface/subsurface flow paths (non-point sources). Evidence of this human influence can be found, 
for instance, in world-wide increases in stream nutrient loads, especially nitrogen (Vitousek et al., 1997).

In industrial countries, wastewater treatment plants (WWTP) modify punctually water quality through nitrogen, phosphor and organic matter input (Merseburger et al., 2005). Changes in the availability of organic matter affect stream metabolism (Crenshaw et al., 2002) and the abundance and composition of stream communities (Prenda and Gallardo-Mayenco, 1996).

Nutrient retention is a functional property of stream ecosystems that may contribute to counteract stream water quality problems. Stream nutrient retention depends on water residence time (i.e., hydrologic retention), as well as on biological and chemical processes affecting nutrient transport (Billen and Garnier, 1999; House et al., 2001) and also on the interaction of several physical (morphology and hydrology), chemical, and biological mechanisms (Lefebvre et al., 2006). At the reach scale, streambed permeability favors water exchanges between surface and hyporheic porous media, causing a physical delay in nutrient transport. This physical delay, coupled with biological activity within the sediment, suggests that the stream surface-subsurface hydrological linkage may be an important factor in enhancing stream nutrient retention, at least in non-polluted streams (Valett et al., 1997; Fisher et al., 1998).

In order to assess modifications of biogeochemical transformation efficiencies in streams altered by human activity, a multidisciplinary study was carried out in the Lèze watershed (SW France). Hydro-morphology, chemical water quality, nutrient uptakes rates, respiration, growth primary production and benthic invertebrate community structure were simultaneously measured. The experimental sites, located in two distinct parts of the watershed were selected to represent two contrasting nutrient source conditions: in the upper part of the catchment, the Montégut site with mainly nutrient point sources and in the downstream part of the catchment, the Lézat site with mainly non-point-source nutrients. Both experimental sites were located on reaches including a WWTP nutrient source, enabling a study of the relative effects of point-source and non-point-source nutrient loads on the biogeochemical function. For each reach, two sub-reaches with the same geomorphological characteristics were studied: one upstream of the WWTP and the second downstream of the effluent discharge. Pointsource effects on uptake rates may be demonstrated by comparing processes and biological features (uptake rates, chemistry, metabolism, invertebrates, biofilm) of the two sub-reach. Non-point-source nutrient load effects may be determined by comparing the uptake rates and associated processes at a site between the upper and the lower catchment.

Some previous papers show that increased nutrient loads increase areal nutrient uptake but decrease nutrient uptake efficiencies (longer uptake lengths) (see Paul and Meyer, 2001; Haggard et al., 2005; Gucker et al., 2006). In the Lèze catchment, we hypothesizes that river nutrient pollution controls biological metabolism and invertebrate assemblage structure but that these chemical modifications do not influence nutrient retention comparing two subreaches with the same geomorphological characteristics.

\section{Materials and methods}

\section{Study site}

The Lèze river $\left(10^{\circ} 24^{\prime} \mathrm{E}, 43^{\circ} 28^{\prime} \mathrm{N}\right)$ is a third-order stream $70 \mathrm{~km}$ long, tributary of the Ariège river, located $20 \mathrm{~km}$ south-west of Toulouse in southern France. The mean riverbed is approximately $5 \mathrm{~m}$ with a slope less than $1 \%$. The watershed is $350 \mathrm{~km}^{2}$, with a total length of $48 \mathrm{~km}$ and a width of around $8 \mathrm{~km}$. This river takes its source at the Mondély dam (590 m alt.). From its source to the confluent with the Ariège river, it drains 135 tributaries and crosses two substratum types. The basin topography can be divided into two parts: the upper part of the basin in a region of low mountains on calcareous rock and the lower part in an alluvial floodplain with a clay, silt and silica substratum. The density of drainage is $1.63 \mathrm{~km} . \mathrm{km}^{-2}$ for the whole watershed, but differs between the upper $\left(2.42 \mathrm{~km} . \mathrm{km}^{-2}\right)$ and lower $\left(1.47 \mathrm{~km} . \mathrm{km}^{-2}\right)$ parts.

Land use (Fig. 1) indicates the various types of natural and anthropological areas within the watershed. More than $80 \%$ of total area of the watershed is agricultural, with mainly cereal crops. Natural areas (woodland, forest and natural grassland) are much more frequent in the upper part of the basin. The population (basin total of 24959 habitants) is mainly in the lower part of the basin in a dozen towns and villages.

Average annual precipitation was $710 \mathrm{~mm}$ for $1985-$ 1995 and is generally uniform for the whole basin (MétéoFrance data). The annual average temperature is around $14{ }^{\circ} \mathrm{C}$ with an annual amplitude of $10.5{ }^{\circ} \mathrm{C}$. The hydrological regime of the Lèze River is pluvial with periods of rapid floods in springs and a very pronounced low water period which can occurs from the beginning of the summer (June) until winter even until the beginning of the next spring (March). The Regional Environmental Agency continuously measures discharge at two hydrological stations (Lézat and Labarthe-sur-Lèze). At the Labarthe station, the annual average discharge is $2.06 \mathrm{~m}^{3} \cdot \mathrm{s}^{-1}$, with an average discharge during the low-water period of $0.14 \mathrm{~m}^{3} \cdot \mathrm{s}^{-1}$ and a maximal daily discharge of $110 \mathrm{~m}^{3} \cdot \mathrm{s}^{-1}$. The flow is partially controlled during the summer by the Mondély dam.

\section{Data collection}

\section{Along the whole river}

In order to study the biogeochemistry of the river ten stations were selected along the whole length of the Lèze River (Fig. 1). Three stations are located in the upstream part of the basin and seven downstream. The Mondély dam station is particular as dam releases could alter 

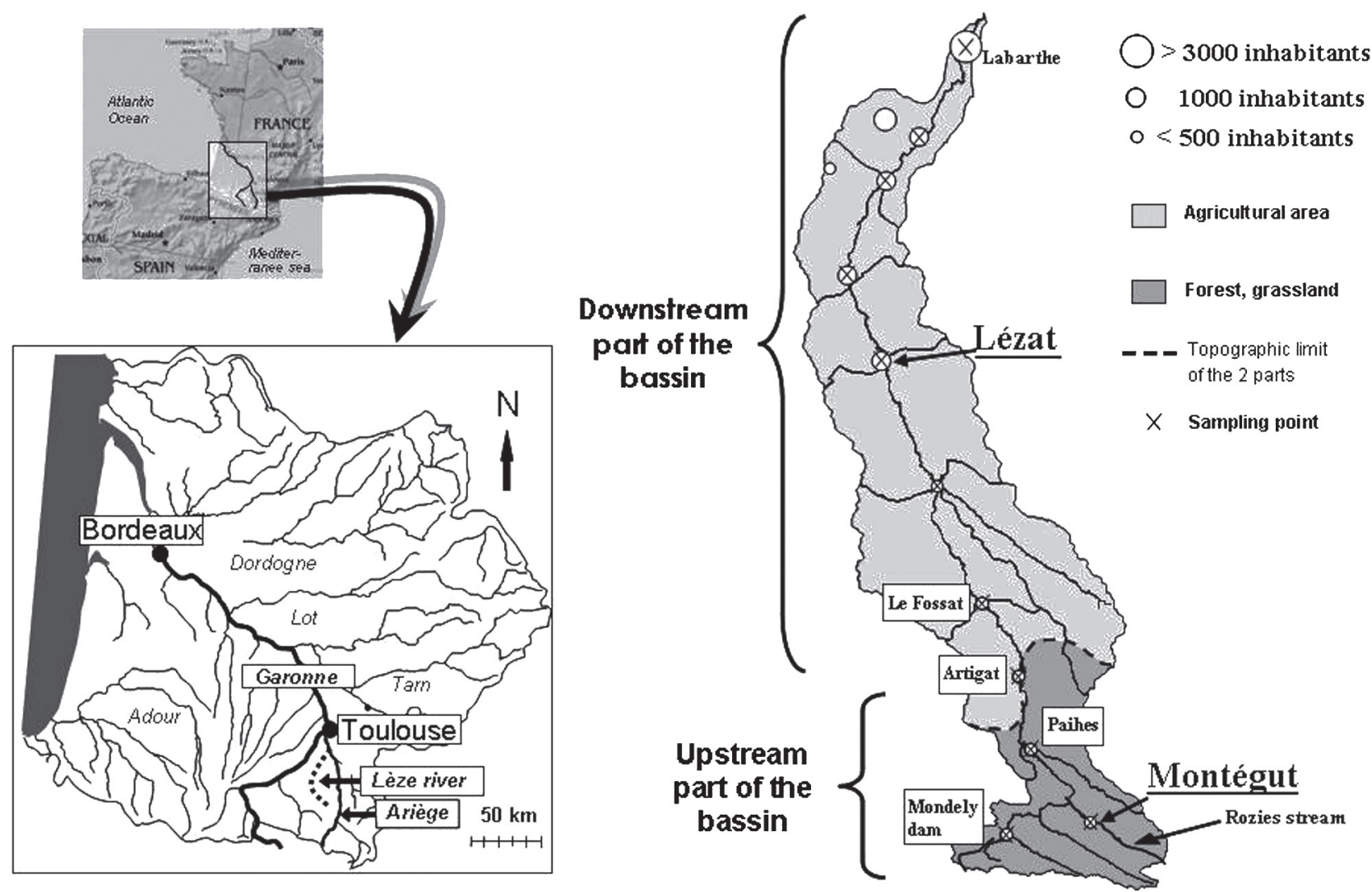

Fig. 1. Location of Lèze river, distribution of land use and population in the watershed and position of sampling sites.

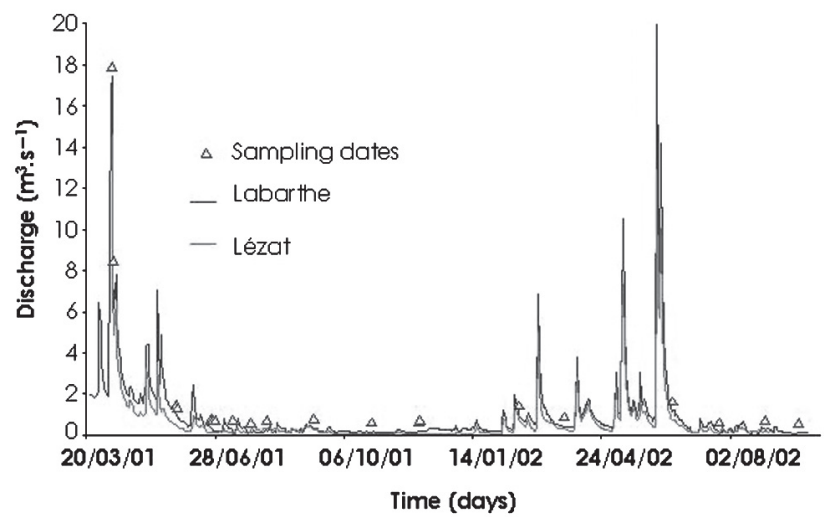

Fig. 2. Mean daily discharge at Labarthe and Lézat from 04/09/ 2001 to 24/09/2002 (data from French Regional Environmental Agency).

the biogeochemistry of the course. Samples were taken over a whole year from $04 / 09 / 2001$ to $24 / 09 / 2002$ (Fig. 2) at an average frequency of one month in order to study different hydrological conditions (low water periods, mean water period and flood periods). The number of sampling dates for each station varied from 12 to 20 as floods sometimes made sampling stations inaccessible.

Temperature, dissolved oxygen, conductivity and $\mathrm{pH}$ were measured in situ with a multi-parameter probe (YSI 6920). Water samples were collected in plastic bottles and filtered through glass fibre filters (Whatman GFF $0.7 \mu \mathrm{m}$ ) for measure soluble fraction. Total nitrogen and total phosphorus were measured in raw water. Nitrate $\left(\mathrm{NO}_{3}^{-}-\mathrm{N}\right)$, ammonium $\left(\mathrm{NH}_{4}^{+}-\mathrm{N}\right)$ and phosphate $\left(\mathrm{PO}_{4}^{3-}-\mathrm{P}\right)$ concentrations were analysed by High Performance Ionic Chromatography (HP-IC) using a DIONEX system. Total nitrogen (TN), total dissolved nitrogen (TDN), total phosphorus (TP) and total dissolved phosphorus (TDP) were analysed by colorimetric methods (Rodier, 1996). Detection level for nitrate $\left(\mathrm{NO}_{3}^{-}-\mathrm{N}\right)$, ammonium $\left(\mathrm{NH}_{4}^{+}-\mathrm{N}\right)$ and phosphate $\left(\mathrm{PO}_{4}^{3-}-\mathrm{P}\right)$ was respectively $0.01,0.008$ and $0.005 \mathrm{mg} . \mathrm{L}^{-1}$.

\section{At the study site scale}

Two study sites were investigated: the first, called Montégut, was located in the Rozies stream, close to the village of Montégut-Plantaurel. This site is characterized by a point source of pollution stronger than the non-point sources; water is also lost by going underground. At this site, the capacity of the WWTP is planned for 500 inhabitants, with a secondary biological treatment applied only to nitrogen. The second study site, called "Lézat" was located in the Lèze stream, near the city of Lézat. At this second site, the WWTP capacity is for 2500 inhabitants with the same treatment as Montégut. This site is characterized by non-point source pollution exceeding the point source; there is a net gain of nutrient 
from groundwater. Nitrogen fluxes (total Kjeldahl nitrogen (TKN) and $\mathrm{NH}_{4}^{+}$) coming from the two WWTP were measured over two days per year by the water-treatment plant technical support and study service (SATESE).

The choice of these two sites was based on two criteria: the sites were located in the two parts of the watershed such that each had different surface water-groundwater interactions and both sites included a waste-water treatment plant. Each site was subdivided into two sub-reaches with the same geomorphological characteristics, upstream (US) and downstream (DS) of the WWTP effluent discharge. The downstream sub-reach starts at $108 \mathrm{~m}$ of the WWTP for Montégut site and $128 \mathrm{~m}$ for Lézat site. Reach slope is $1 \%$ from Montégut site and $0.18 \%$ from Lézat site. At each site, six dates were chosen to measure stream functioning under different hydrological conditions. For each date and for each sub-reach, morphological and physical descriptors, water chemical parameters, metabolism and biological compartments (biofilm and invertebrates) were investigated.

\section{Stream nutrient retention measurements}

To estimate the stream nutrient $\left(\mathrm{NH}_{4}^{+}-\mathrm{N}, \mathrm{NO}_{3}^{-}-\mathrm{N}\right.$, and $\mathrm{PO}_{4}^{-3}-\mathrm{P}$ ) retention, on each sampling date we performed additions of known concentrations of both a nutrient $\mathrm{NH}_{4}^{+}-\mathrm{N}, \mathrm{NO}_{3}^{-}-\mathrm{N}$, or $\mathrm{PO}_{4}^{-3}-\mathrm{P}$ ) and a conservative element $\left(\mathrm{Cl}^{-}\right)$into the stream as a tracer of downstream dilution for corrections. At each experimental sub-reach (upstream and downstream of the WWTP) two additions were made per sampling date. The additions can be done in rapid succession around midday on the same date if the environmental conditions (mostly water discharge and light) allow it.

Short-term nutrient addition was performed at constant rate; however, when the quantity of nutrient required to increase the background concentration and bring concentrations to a new plateau was too high, we used an alternative solute addition method (slug addition). $\mathrm{NH}_{4}^{+}-\mathrm{N}$ and $\mathrm{PO}_{4}^{3-}-\mathrm{P}$ uptake rates were determined using solute additions conducted at constant rates (short-term nutrient addition procedure) and $\mathrm{NO}_{3}^{-}-\mathrm{N}$ uptake rates were determined using instantaneous solute addition (slug addition). The first addition (constant rate) contained $\mathrm{NH}_{4}^{+}+\mathrm{H}_{2} \mathrm{PO}_{4}^{-}+\mathrm{Cl}^{-}$and the second (slug addition) contained $\mathrm{NO}_{3}^{-}+\mathrm{H}_{2} \mathrm{PO}_{4}^{-}+\mathrm{Cl}^{-}$. Note that phosphate has to be added to both the nitrate and the ammonium additions to keep $\mathrm{N}: \mathrm{P}$ ratios similar for the stream. Phosphate retention was calculated using data only from the first addition. A similar increase in phosphorus concentration was used for both nitrogen additions.

The constant rate short-term nutrient addition procedure and the slug addition procedure provided some indicators of the biogeochemical function of the streams at the reach scale. The two methods are complementary and allow the determination of the nutrient uptake length $\left(\mathrm{S}_{\mathrm{w}}\right)$, nutrient uptake rate coefficient $\left(\mathrm{K}_{\mathrm{c}}\right)$ and mass transfer coefficient $\left(\mathrm{V}_{\mathrm{f}}\right)$ and uptake rate calculation $(\mathrm{U})$.

\section{Slug addition procedure}

Nutrient removal efficiency estimated using the slug addition technique was made according to the procedure of Gordon et al. (1994) and applied by Ruggiero et al. (2006) in a similar study in Italy. A known volume of solution (e.g., nutrients + conservative tracer) was added all at once from a carboy in the midchannel at the top end of the reach. Once the solution was added, water samples were collected at regular intervals (about 1 every minute) at the bottom end of the reach with an increase in frequency (up to 1 every 5 seconds) during the solution's passage (which was detected by an increase of the stream background conductivity). The collection of samples stopped when conductivity values were at the same level as measured previous to the release. Concentration-time curve $\left(\mathrm{mg} . \mathrm{L}^{-1} \times \mathrm{s}\right)$ of nutrient $\left(\mathrm{PO}_{4}^{-}-\mathrm{P}, \mathrm{NH}_{4}^{+}-\mathrm{N}\right.$ and $\mathrm{NO}_{3}^{-}-\mathrm{N}$ ) and conservative tracer (i.e. $\mathrm{Cl}^{-}$) were then used to calcula calculate the mass (mg) of nutrient retained (see details of addition experiment, chemical analyses and calculation in Ruggiero et al., 2006). We calculated the nutrient uptake rate $\left(\mathrm{U}, \mathrm{mg} \cdot \mathrm{m}^{-2} \cdot \mathrm{min}^{-1}\right)$ by dividing the mass of nutrient removed from the water column during the addition experiment by the stream bottom area $\mathrm{A}\left(\mathrm{m}^{2}\right)$ of the reach and by the time $\mathrm{T}(\mathrm{min})$ of the duration of the addition. The nutrient uptake length $\left(S_{w}, m\right)$ was then estimated from: $S_{w}=([N u t] b * Q) /(U * w)$ where $[N u t] b$ is the nutrient background concentration (mg. $\mathrm{L}^{-1}$ ), $\mathrm{Q}$ is the discharge $\left(\mathrm{m}^{3} \cdot \mathrm{s}^{-1}\right), \mathrm{U}$ is the nutrient uptake rate $\left(\mathrm{mg} \cdot \mathrm{m}^{-2} \cdot \mathrm{s}^{-1}\right)$ and $\mathrm{w}(\mathrm{m})$ is the average stream width of the reach. The nutrient uptake velocity $\left(\mathrm{V}_{\mathrm{f}}, \mathrm{mm} . \mathrm{s}^{-1}\right)$ was estimated from: $\mathrm{V}_{\mathrm{f}}=\mathrm{U} /[\mathrm{Nut}] \mathrm{b}$ where $\mathrm{U}$ is the nutrient uptake rate $\left(\mathrm{mg} \cdot \mathrm{m}^{-2} \cdot \mathrm{s}^{-1}\right)$, [Nut]b is the nutrient background concentration (mg. $\left.\mathrm{L}^{-1}\right)$.

\section{Short-term nutrient addition procedure}

Nutrient removal efficiency was estimated using the constant rate short-term nutrient addition procedure according to the procedure of The Stream Solute Workshop (1990). The basis of this calculation is to compare the pattern of the tracer concentration and of the nutrient concentration along six points of each sub-reach. Decreases in nutrient concentration along the reach at plateau will follow a similar pattern to decreases in tracer concentration at plateau if the nutrient is not being retained along the sub-reach. Then, downstream changes in nutrient concentration will only be due to water advection, dispersion, and dilution. However, if decreases in nutrient concentration at plateau are more pronounced than those of tracer concentration at plateau, we may attribute these changes to biotic and abiotic retention processes occurring within the reach.

To calculate nutrient uptake length, nutrient concentration at plateau conditions $\left(\mathrm{C}_{\mathrm{p}}, \mathrm{mg} . \mathrm{L}^{-1}\right)$ must be corrected by background nutrient concentration $\left(\mathrm{C}_{\mathrm{b}}, \mathrm{mg} . \mathrm{L}^{-1}\right)$ at each sampling point. The corrected value is calculated by subtracting background from plateau concentration at each point $\left(\right.$ i.e., $\left.\left(\mathrm{C}_{\mathrm{p}}-\mathrm{C}_{\mathrm{b}}\right)_{\mathrm{x}}\right)$. This difference 
will gradually decrease along the reach if there is some 'loss' of nutrient. The tracer concentration also must be corrected by subtracting background concentration $\left(\mathrm{T}_{\mathrm{b}}, \mathrm{mg} . \mathrm{L}^{-1}\right)$ from plateau concentration $\left(\mathrm{T}_{\mathrm{p}}, \mathrm{mg} . \mathrm{L}^{-1}\right)$ at each sampling point. If the reach does not have any lateral or vertical water inputs, corrected chloride concentration (i.e., $\left.\left(\mathrm{T}_{\mathrm{p}}-\mathrm{T}_{\mathrm{b}}\right)_{\mathrm{x}}\right)$ must be similar at all sampling points:

$$
\operatorname{Ln}\left[\frac{C_{p}-C_{b}}{T_{p}-T_{b}}\right]_{x}=-K x .
$$

Once concentrations have been corrected, we calculate the ratio of the corrected nutrient over the corrected tracer at each point. If the nutrient is being biotically or abiotically removed, this ratio will follow a negative exponential curve along the reach. Assuming a constant uptake rate along the reach, the following equation describes the change along the reach of the natural logarithm of this ratio: where $K$ (the slope of this function) is the downstream nutrient change coefficient $\left(\mathrm{m}^{-1}\right)$ and $\mathrm{x}$ is the distance of each sampling point from the addition site $(\mathrm{m})$. The negative inverse of $\mathrm{K}(-1 / \mathrm{K})$ is an estimate of the reach nutrient retention efficiency, expressed in units of length. This parameter is the nutrient uptake length $\left(\mathrm{S}_{\mathrm{w}}, \mathrm{m}\right)$. Shorter distances suggest greater nutrient retention efficiency than longer distances.

Variations in water velocity and discharge can influence nutrient uptake length (see Butturini and Sabater, 1998). Correcting the value for these hydrologic parameters is useful to compare this parameter among different stream ecosystems, or between different dates in a single stream. Nutrient uptake rate coefficient $\left(\mathrm{K}_{\mathrm{c}}, 1 / \mathrm{s}\right)$ describes uptake on a volumetric basis instead of as a flux to the stream bottom. This parameter is related to the nutrient uptake length as follows:

$$
\mathrm{K}_{\mathrm{c}}=\frac{\mathrm{v}}{\mathrm{S}_{\mathrm{w}}}
$$

where $S_{w}$ is the nutrient uptake length $(\mathrm{m})$ and $\mathrm{v}$ is the average water velocity (m.s $\left.{ }^{-1}\right)$.

The mass transfer coefficient $\left(\mathrm{V}_{\mathrm{f}}, \mathrm{m} . \mathrm{s}^{-1}\right)$ is the vertical velocity at which a solute migrates through the sedimentwater interface. This parameter is related to the uptake rate coefficient $\left(K_{c}, 1 / s\right)$ through average water depth $(\mathrm{d}, \mathrm{m})$ as follows:

$$
\mathrm{V}_{\mathrm{f}}=\mathrm{d} * \mathrm{~K}_{\mathrm{c}}=(\mathrm{d} * \mathrm{v}) / \mathrm{S}_{\mathrm{w}}
$$

Once we have calculated nutrient uptake length (m), nutrient uptake rate at ambient levels per unit area of stream bottom can be calculated using the following equation:

$$
\mathrm{U}=\frac{\mathrm{C}_{\mathrm{b}} \cdot \mathrm{Q}}{\mathrm{S}_{\mathrm{w}} \cdot \mathrm{W}} \cdot 60
$$

where $\mathrm{U}$ is the nutrient uptake rate $\left(\mathrm{mg} \cdot \mathrm{m}^{-2} \cdot \mathrm{min}^{-1}\right), \mathrm{C}_{\mathrm{b}}$ is the background nutrient concentration $\left(\mathrm{mg} . \mathrm{L}^{-1}\right), \mathrm{Q}$ is stream discharge $\left(\mathrm{L} . \mathrm{s}^{-1}\right), \mathrm{S}_{\mathrm{w}}$ is the nutrient uptake length $(\mathrm{m}), \mathrm{w}$ is the average stream width in the reach $(\mathrm{m})$, and 60 is a constant for converting seconds to minutes.
An alternative formula to calculate nutrient uptake rate at ambient levels based on the nutrient uptake length is (Stream Solute Workshop, 1990):

$$
\mathrm{U}=\frac{\mathrm{C}_{\mathrm{b}} \cdot \mathrm{h} \cdot \mathrm{V}}{\mathrm{S}_{\mathrm{w}}} \cdot 60
$$

where $\mathrm{U}$ is the nutrient uptake rate $\left(\mathrm{mg} \cdot \mathrm{m}^{-2} \cdot \mathrm{min}^{-1}\right), \mathrm{C}_{\mathrm{b}}$ is the background nutrient concentration $\left(\mathrm{mg} \cdot \mathrm{m}^{-3}\right), \mathrm{h}$ is the water average depth $(\mathrm{m}), \mathrm{v}$ is the average stream water velocity $\left(\mathrm{m} . \mathrm{s}^{-1}\right), \mathrm{S}_{\mathrm{w}}$ is the nutrient uptake length $(\mathrm{m}), \mathrm{w}$ is the average stream width in the reach $(\mathrm{m})$, and 60 is a constant for converting seconds to minutes.

\section{Metabolism measurements}

For stream metabolism estimations, three types of measurement were performed: environmental parameters (water temperature, light and discharge), re-aeration rates and dissolved oxygen concentrations in the upstream and downstream parts of each sub-reach. Water temperature was recorded at 15 minute intervals with a YSI probe. Global sunlight irradiation $\left(\mathrm{mol} . \mathrm{m}^{-2} \cdot \mathrm{d}^{-1}\right)$ were measured at the Muret station by Météo France (the national meteorological office) i.e. $10 \mathrm{~km}$ from Lézat site. Discharge data were provided by the French Regional Environmental Agency for the Lézat and Labarthe sites.

Re-aeration rates were determined experimentally at the Montégut site using butane injections (Marzolf et al., 1994). The re-aeration rates obtained were compared to empirical estimations (O'Connor and Dobbins, 1958; Owens et al., 1964; Isaacs and Gaudy, 1968) using water velocity and depth, to determine the most suitable method for in situ $\mathrm{K}_{\text {oxy }}$ measurement. According to Marzolf et al. (1994), $\mathrm{K}_{\text {oxy }}$ $\left(\mathrm{min}^{-1}\right)$ from butane injection is calculated as follows:

$$
\mathrm{K}_{\text {oxy }}=\mathrm{S} * \mathrm{~V} * 60 * \mathrm{~F}
$$

$\mathrm{S}\left(\mathrm{m}^{-1}\right)$ is the slope of the plot of Ln (butane/chloride) versus the distance from the injection point, $\mathrm{V}\left(\mathrm{m} . \mathrm{s}^{-1}\right)$ is the average water velocity, and $F$ is the factor used to convert butane diffusion rates into oxygen diffusion rates $\left(\mathrm{F}=1.82\right.$, Rathbun et al., 1978). Since $\mathrm{K}_{\text {oxy }}$ rates obtained with Owens et al. (1964) empirical method best fitted our measured values and as this method is recommended when water velocity is between 0.3 and $0.5 \mathrm{~m} . \mathrm{s}^{-1}$ and depth between 0.2 and $0.3 \mathrm{~m}$ (Chapra et al., 1997), we used it to estimate the re-aeration rates for the other dates. At the Lézat site, the lack of butane injection results did not enable us to validate a specific method for re-aeration rate estimation and, considering the stream's prevailing hydraulic conditions, the method of Thyssen et al. (1987) was applied. $\mathrm{K}_{\text {oxy }}$ were corrected as a function of water temperature $\left(\mathrm{T}^{\prime}\right)$ using:

$$
\mathrm{K}_{\text {oxy }}\left(\mathrm{T}^{\prime}\right)=\mathrm{K}_{\text {oxy }}(\mathrm{T}) *\left(1+\left(\left(\mathrm{T}^{\prime}-\mathrm{T}\right) * 0.0241\right)\right) .
$$

Gross primary production rate (GPP), net primary production NPP $(\mathrm{GPP}-\mathrm{R})$ and ecosystem respiration $(\mathrm{R})$ were estimated using the upstream-downstream diurnal dissolved oxygen change technique (Marzolf et al., 1994; Young and Huryn, 1998; Mulholland et al., 2001). 
DO variation along a sub-reach is controlled by metabolism and re-aeration flux. The metabolism experiment was run in both the upstream and downstream subreaches. Dissolved oxygen was measured at the top end and the bottom end of the experimental sub-reaches in the centre of the river at half the total water depth. DO levels were recorded at 15 -minute intervals over a 24 -h period. $\mathrm{Re}$-aeration flux in water $\left(\mathrm{RF}, \mathrm{mg} \mathrm{O}_{2} . \mathrm{s}^{-1}\right)$ was calculated based on the average oxygen saturation deficit or excess within the study reach and the re-aeration rate corrected for temperature, transfer time ( $\mathrm{min}$ ), and discharge $\left(\right.$ L.S $\left.{ }^{-1}\right)$ :

$$
\mathrm{RF}=\mathrm{DO} \text { deficit } * \mathrm{~K}_{\mathrm{oxy}} * \text { transfer time } * \mathrm{Q} .
$$

The net rate of oxygen change between the top and bottom end of each sub-reach as a result of metabolism (equivalent to net ecosystem production) was then determined from the change in mass flux of dissolved oxygen between stations corrected for air-water exchange of oxygen within the reach. The daily rate $\mathrm{R}$ was calculated by summing the net oxygen change rate measured during the night and the daytime rate $\mathrm{R}$ determined by extrapolating the net oxygen change rate during 1-h pre-dawn and post-dusk periods. The daily rate of GPP was determined by summing the differences between measured net oxygen change rate and the extrapolating value of $\mathrm{R}$ during the daylight period. All metabolism rates, $\mathrm{R}$ $\left(\mathrm{g} \mathrm{O}_{2} \cdot \mathrm{m}^{-2} \cdot \mathrm{d}^{-1}\right)$ and GPP $\left(\mathrm{g} \mathrm{O}_{2} \cdot \mathrm{m}^{-2} \cdot \mathrm{d}^{-1}\right)$ were converted to rates per unit area by dividing the area of stream bottom between the two stations. The daily rate of NPP was calculated as the difference between the daily rate of GPP and corrected by R.

\section{Invertebrate sampling}

Invertebrates were sampled on six dates between 2001 and 2002: four dates for the Montégut site and two dates for the Lézat site (Table 1). Invertebrates were collected along the reaches using a Surber sampler $\left(12.25 \mathrm{dm}^{2}\right.$ with $200 \mu \mathrm{m}-\mathrm{mesh}$ size). Twelve stations per reach were investigated (six upstream/six downstream from the WWTP); at each station two replicates were taken with respect to microhabitat distributions. Granulometry, water velocity, water depth and the concentrations of the main dissolved nutrients (nitrite, nitrate, ammonium and phosphate) were recorded simultaneously.

In the laboratory, organisms were sorted under a stereomicroscope. For samples with very high animal densities, sub-sampling was used. For the purposes of our study, the majority of the specimens were not identified past family; functional feeding groups (FFG hereafter) were then constituted following Tachet et al. (2000), Puig (1999), Pennak (1978), Merritt and Cummins (1984). Considered FFG were: scrapers (SCRA), filtering collectors (COLfi), shredders (SHRE), gathering collectors (COLga), predators (PRE). Dry biomass was estimated for each FFG after drying the specimens at $40{ }^{\circ} \mathrm{C}$ for four days. Micro-habitats were characterized using granulometry, water velocity, water depth and dissolved nutrient concentrations for nitrites, nitrates, ammonium and phosphates after filtering through $0.7 \mu \mathrm{m}$ mesh.

\section{Processing the data}

Statistical data processing was performed using Minitab software (Minitab Inc.). Mann-Whitney tests were run to compare upstream and downstream data. Regression was applied to test the effect of environmental factors. Values were considered significant when $P<0.05$. For invertebrates, the Kruskal-Wallis test was used to compare up- and down-stream density and biomass. Spatial variations of the invertebrate assemblage characteristics were investigated along the longitudinal river gradient using multi-factorial ANOVA. The influence of reach location (up- or downstream of the WWTP) and potential interaction effects with FFG were tested using invertebrate density and biomass after log-transformation of data.

\section{Results}

\section{Geochemistry on the scale of the river}

Total dissolved nitrogen (TDN) and $\mathrm{NO}_{3}^{-}-\mathrm{N}$ represent respectively $81 \%$ and $57 \%$ of the total nitrogen (TN). TN, TDN and $\mathrm{NO}_{3}^{-}-\mathrm{N}$ concentrations increased from upstream to downstream of the river while $\mathrm{NO}_{4}^{+}-\mathrm{N}$ decreased (Fig. 3). Statistical tests showed that the concentrations of all nitrogen forms were significantly different (ANOVA, $P<0.05)$ between stations $(n=8$ to 20$)$ and between upstream and downstream parts of the watershed $(n=62$ upstream, $n=85$ downstream). TN and TDN concentrations measured in the upstream part of the basin were three-fold lower than those measured downstream and $\mathrm{NO}_{3}^{-}-\mathrm{N}$ concentrations were nine-fold lower. In the upstream part, concentrations of $\mathrm{NH}_{4}^{+}-\mathrm{N}$ concentrations were 10 -fold greater than $\mathrm{NO}_{3}^{-}-\mathrm{N}$ concentrations. In the downstream part $\mathrm{NH}_{4}^{+}-\mathrm{N}$ concentration were half that of $\mathrm{NO}_{3}^{-}-\mathrm{N}$. In the downstream part, $\mathrm{NO}_{3}^{-}-\mathrm{N}$ was the main form in TN $(32 \%$ in the upstream part and $81 \%$ in the downstream part).

Total dissolved phosphorus (TDP) represented $59 \%$ of TP and $\mathrm{PO}_{4}^{-3}-\mathrm{P}$ represented less than $1 \%$ of TP. Statistical tests showed that all the levels of all forms of phosphorus differed significantly (ANOVA, $P<0.05$ ) between stations and between upstream and downstream parts of the basin. TP concentrations measured upstream were one third those measured downstream $\left(18 \mu \mathrm{g} . \mathrm{L}^{-1}\right.$ and $\left.65 \mu \mathrm{g} . \mathrm{L}^{-1}\right)$ and TDP concentrations six-fold lower $\left(6 \mu \mathrm{g} . \mathrm{L}^{-1}\right.$ and $\left.39 \mu \mathrm{g} . \mathrm{L}^{-1}\right)$.

\section{Stream biogeochemistry on the scale of the study site}

\section{Waste water treatment plant discharge}

At Montégut and Lézat sites, TN fluxes from the WWTP were respectively 5 and $32.5 \mathrm{~kg} \mathrm{~N}$.d $^{-1}$ and 
Table 1. Physical parameter, background and increased in concentrations for $\mathrm{NH}_{4}^{+}-\mathrm{N}, \mathrm{NO}_{3}^{-}-\mathrm{N}$ and $\mathrm{PO}_{4}^{-3}-\mathrm{P}$ in the two experimental reaches (US and DS) for each addition experimental date from the two sites (Montégut and Lézat). - = not available.

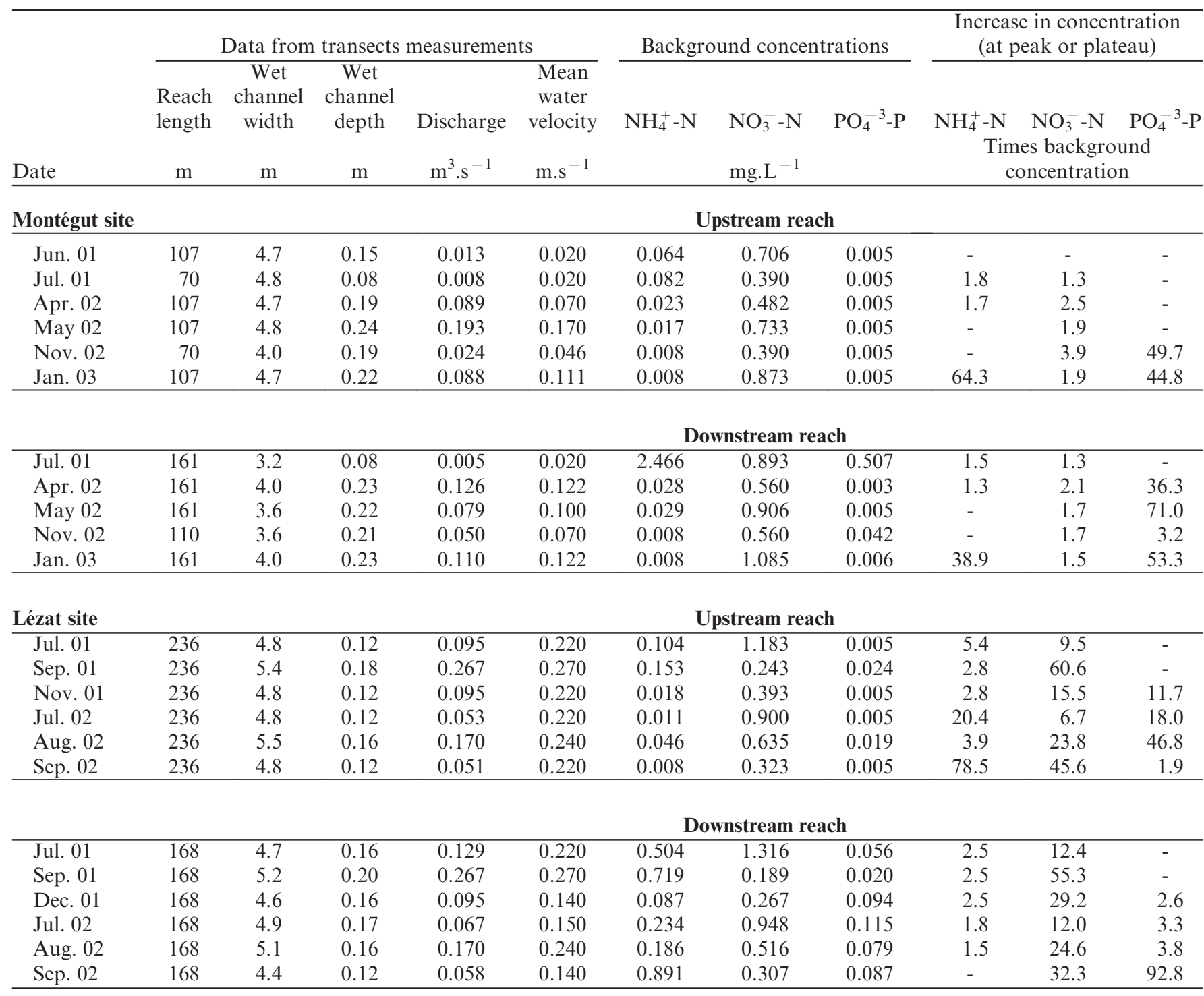

$\mathrm{NH}_{4}^{+}-\mathrm{N}$ fluxes, 5 and $25 \mathrm{~kg} \mathrm{~N} . \mathrm{d}^{-1}$. So, the results showed that $\mathrm{N}$-org fluxes, obtained by the difference between $\mathrm{TN}$ and $\mathrm{NH}_{4}^{+}-\mathrm{N}$ fluxes, were near $0 \mathrm{~kg} \mathrm{~N} . \mathrm{d}^{-1}$ from Montégut WWTP and around $7.5 \mathrm{~kg} \mathrm{~N} . \mathrm{d}^{-1}$ at Lézat. At Montégut and Lézat sites, with mean discharges during experiments of $0.07{\mathrm{~L} . \mathrm{s}^{-1}}^{-1}$ and $0.12{\mathrm{~L} . \mathrm{s}^{-1}}^{-1}$ respectively, mean fluxes circulating in the river were respectively $0.6 \mathrm{~kg} \mathrm{~N} . \mathrm{d}^{-1}$ and $4.1 \mathrm{~kg} \mathrm{~N} . \mathrm{d}^{-1}$ for $\mathrm{NH}_{4}^{+}$and 1.2 and $2.0 \mathrm{~kg} \mathrm{~N} . \mathrm{d}^{-1}$ for N-org.

\section{Stream nutrient retention}

Uptake rate ranged from $-1.419 \mathrm{mg} \cdot \mathrm{m}^{-2} \cdot \mathrm{min}^{-1}$ $\left(\mathrm{NO}_{3}^{-}-\mathrm{N}\right.$, DS reach, April) to $1.785\left(\mathrm{NH}_{4}^{+}-\mathrm{N}, \mathrm{DS}\right.$ reach, April) at the Montégut site and from $-0.025\left(\mathrm{PO}_{4}^{-3}-\mathrm{P}\right.$, DS reach, September) to $3.221\left(\mathrm{NH}_{4}^{+}-\mathrm{N}\right.$, DS reach, September) at the Lézat site (Table 2). On average, uptake rate was higher in downstream sub-reaches than in upstream sub-reaches for $\mathrm{NH}_{4}^{+}-\mathrm{N}$ and $\mathrm{PO}_{4}^{-3}-\mathrm{P}$ at both sites and for $\mathrm{NO}_{3}^{-}-\mathrm{N}$ at Lézat, but this difference was not statistically significant (ANOVA, $P>0.05$ ). Uptake rates did not differ between sites for any nutrients (ANOVA, $P>0.05)$.

\section{Metabolism}

Rates of respiration $\left(\mathrm{R}, \mathrm{g} \mathrm{O}_{2} \cdot \mathrm{m}^{-2} \cdot \mathrm{d}^{-1}\right)$ and net primary production (NPP, $\mathrm{g} \mathrm{O}_{2} \cdot \mathrm{m}^{-2} \cdot \mathrm{d}^{-1}$ ) estimated for both experimental sites are reported in Table 3. During the study periods, discharge ranged between 86 and 414 L.s ${ }^{-1}$ at Lézat site and between 15 and $116{\mathrm{~L} . \mathrm{s}^{-1}}^{-1}$ at Montégut site. The experimental distance between the top and bottom ends of the sub-reaches ranged from $168 \mathrm{~m}$ to $236 \mathrm{~m}$ at Lézat and 106 to $159 \mathrm{~m}$ at Montégut depending on the water velocity. Water travel time was between 9.2 and $18 \mathrm{~min}$ at Lézat and between 3.8 and $88 \mathrm{~min}$ at Montégut. Daily solar radiation for the experimental dates varied from 9.9 to $42.7 \mathrm{~mol} . \mathrm{m}^{-2} \cdot \mathrm{d}^{-1}$. 

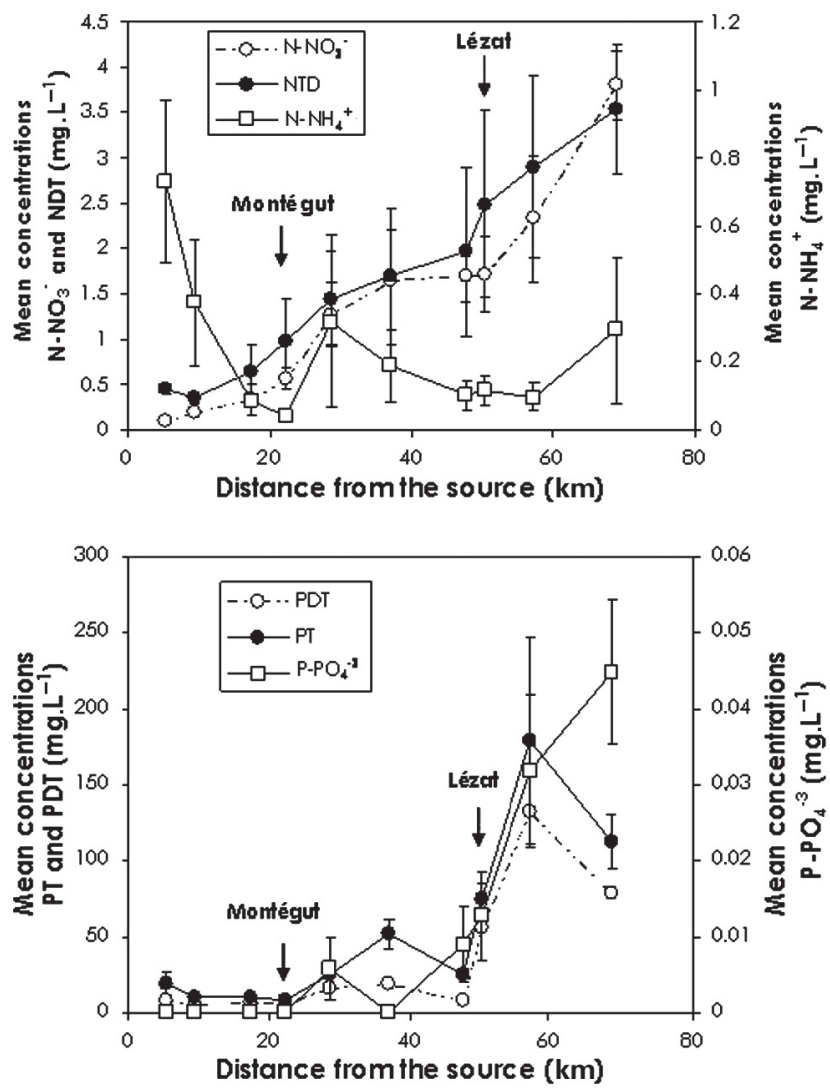

Fig. 3. Longitudinal concentration of nitrate $\mathrm{NO}_{3}^{-}-\mathrm{N}$, ammonium $\mathrm{NH}_{4}^{+}-\mathrm{N}$, total dissolved nitrogen TDN, total nitrogen TN and $\mathrm{PO}_{4}^{-3}-\mathrm{P}$, total phosphorus (TP), total dissolved phosphorus (TDP) over the whole basin.

Daily rates of metabolism varied considerably at both sites with $\mathrm{R}$ ranging between 2.4 and $84.8 \mathrm{~g} \mathrm{O}_{2} \cdot \mathrm{m}^{-2} \cdot \mathrm{d}^{-1}$ at Lézat and from 1.2 to $23.0 \mathrm{~g} \mathrm{O}_{2} \cdot \mathrm{m}^{-2} \cdot \mathrm{d}^{-1}$ at Montégut. Maximal values of respiration rates were generally encountered in spring $(04 / 17$ at Lézat and $05 / 05$ at Montégut), with minimal rates occurring in late spring and summer.

Gross primary production rates (GPP) were equal to zero or were at least very low during summer. Maximal values were $13.8 \mathrm{~g} \mathrm{O}_{2} \cdot \mathrm{m}^{-2} \cdot \mathrm{d}^{-1}$ at Lézat in May and $9.9 \mathrm{~g} \mathrm{O}_{2} \cdot \mathrm{m}^{-2} \cdot \mathrm{d}^{-1}$ at Montégut in April. Since these GPP were usually less than the respiration rates, most of the estimated NPP were negative. Positive, but very low, NPP rates were only estimated at the Montégut site in April in the US sub-reach and in September in the DS sub-reach. The ratio GPP/R followed the same variation as NPP: it was greater than 1 when NPP $>0$. Statistical analyses did not indicate significant differences of respiration rates (except for respiration at the Lézat site), GPP or GPP/R between sites or between US and DS reaches at both sites due to the great variations between dates. NPP rates were significantly greater at the Montégut site $\left(-2.2 \mathrm{~g} \mathrm{O}_{2} \cdot \mathrm{m}^{-2} \cdot \mathrm{d}^{-1}\right)$ than at Lézat $\left(-18.4 \mathrm{~g} \mathrm{O}_{2} \cdot \mathrm{m}^{-2} \cdot \mathrm{d}^{-1}\right)$. At the Lézat site, the respiration rate was significantly $(P<0.05)$ greater in the DS subreach $\left(37.6 \mathrm{~g} \mathrm{O}_{2} \cdot \mathrm{m}^{-2} \cdot \mathrm{d}^{-1}\right)$ than in the US sub-reach
Table 2. Uptake rate (U) estimated for $\mathrm{NH}_{4}^{+}-\mathrm{N}, \mathrm{NO}_{3}^{-}-\mathrm{N}$ and $\mathrm{PO}_{4}^{-3}-\mathrm{P}$ in the two experimental reaches (US and DS) for each addition experimental date from the two sites (Montégut and Lézat). - = data not available.

\begin{tabular}{lccc}
\hline & \multicolumn{3}{c}{$\mathrm{U}\left(\mathrm{mg}^{2} \mathrm{~m}^{2} \cdot \mathrm{min}^{-1}\right)$} \\
\cline { 2 - 4 } Date & $\mathrm{NH}_{4}^{+}-\mathrm{N}$ & $\mathrm{NO}_{3}^{-}-\mathrm{N}$ & $\mathrm{P}^{-\mathrm{PO}_{4}^{-3}}$ \\
\hline Montégut site & \multicolumn{3}{c}{ Upstream reach } \\
\hline Jun. 01 & - & 0.036 & - \\
Jul. 01 & -0.482 & 0.200 & - \\
Apr. 02 & 0.075 & 0.033 & - \\
May 02 & - & 0.003 & - \\
Nov. 02 & - & -0.042 & 0.008 \\
Jan. 03 & -0.022 & -0.008 & 0.023 \\
Mean & -0.143 & 0.037 & 0.016 \\
SE & 0.172 & 0.035 & 0.008 \\
\hline
\end{tabular}

\begin{tabular}{lccc} 
& \multicolumn{3}{c}{ Downstream reach } \\
\hline Jul. 01 & -0.910 & 0.012 & - \\
Apr. 02 & 1.785 & -1.419 & 0.000 \\
May 02 & - & -0.124 & 0.005 \\
Nov. 02 & - & 0.044 & 0.122 \\
Jan. 03 & -0.008 & 0.024 & 0.011 \\
Mean & & & \\
SE & 0.289 & -0.292 & 0.035 \\
& 0.792 & 0.283 & 0.029 \\
\hline
\end{tabular}

\begin{tabular}{lrcc} 
Lézat site & \multicolumn{3}{c}{ Upstream reach } \\
\hline Jul. 01 & 0.163 & 0.036 & - \\
Sep. 01 & 1.440 & 0.200 & - \\
Nov. 01 & -0.007 & 0.033 & 0.025 \\
Jul. 02 & -0.008 & 0.003 & 0.008 \\
Aug. 02 & 0.076 & -0.042 & 0.044 \\
Sep. 02 & -0.005 & -0.008 & 0.003 \\
& & & \\
Mean & 0.277 & 0.037 & 0.020 \\
SE & 0.234 & 0.035 & 0.009 \\
\hline & & & \\
& & Downstream reach & \\
\hline Jul. 01 & 1.211 & 0.014 & - \\
Sep. 01 & 3.221 & 0.327 & - \\
Dec. 01 & 0.043 & 0.020 & 0.098 \\
Jul. 02 & 0.304 & -0.031 & 0.065 \\
Aug. 02 & 2.118 & 0.123 & 0.130 \\
Sep. 02 & & -0.023 & -0.025 \\
& & & \\
Mean & 1.379 & 0.072 & 0.067 \\
SE & 0.588 & 0.056 & 0.033 \\
\hline
\end{tabular}

(5.1 $\left.\mathrm{g} \mathrm{O}_{2} \cdot \mathrm{m}^{-2} \cdot \mathrm{d}^{-1}\right)$. On the experimental reaches, the riparian areas were abundant with mainly deciduous trees. Based on this observation, the effects of season on primary production were tested for two periods: first, the period with no leaves from mid autumn until early spring, and second, the period with leaves the rest of the year. Considering this distinction, a significant effect of season was found to exist for GPP rates with greater mean rates during the leafless period $\left(5.76 \mathrm{~g} \mathrm{O}_{2} \cdot \mathrm{m}^{-2} \cdot \mathrm{d}^{-1}\right)$ than during the period with leaves $\left(0.06 \mathrm{~g} \mathrm{O}_{2} \cdot \mathrm{m}^{-2} \cdot \mathrm{d}^{-1}\right)$. R, NPP rates 
Table 3. Daily rate of ecosystem respiration (R), daily rate of gross primary production (GPP) and net primary production (NPP) estimated for the two experimental reaches (US and DS) for each addition experimental date from the two sites (Montégut and Lézat). In bold are means and standard errors of each reach.

\begin{tabular}{|c|c|c|c|c|}
\hline Date & $\begin{array}{c}\mathrm{R} \\
\mathrm{g} \mathrm{O}_{2} \cdot \mathrm{m}^{-2} \cdot \mathrm{d}^{-1}\end{array}$ & $\begin{array}{c}\text { GPP } \\
\mathrm{g} \mathrm{O}_{2} \cdot \mathrm{m}^{-2} \cdot \mathrm{d}^{-1} \\
\end{array}$ & $\begin{array}{c}\mathrm{NPP} \\
\mathrm{g} \mathrm{O}_{2} \cdot \mathrm{m}^{-2} \cdot \mathrm{d}^{-1} \\
\end{array}$ & GPP/R \\
\hline Montégut site & & Upstream reach & & \\
\hline Apr. 02 & 8.8 & 9.3 & 0.5 & 1.06 \\
\hline May 02 & 1.2 & 0.3 & -0.9 & 0.26 \\
\hline Sep. 02 & 2.7 & 0.6 & -2.1 & 0.23 \\
\hline Jan. 03 & 4.9 & 2.9 & -2 & 0.59 \\
\hline Mar. 03 & 3.5 & 3.2 & -0.3 & 0.92 \\
\hline Mean US & 4.2 & 3.3 & -1.0 & 0.61 \\
\hline SE & 1.3 & 1.6 & 0.5 & 0.17 \\
\hline
\end{tabular}

\begin{tabular}{lrccc} 
& & & & \\
& & & \\
& Downstream reach & -13.1 & \\
Apr. 02 & 23.0 & 9.9 & -1.8 & 0.43 \\
May 02 & 1.8 & 0 & 0.03 & 0.00 \\
Sep. 02 & 1.3 & 1.3 & -2.5 & 1.02 \\
Jan. 03 & 5.9 & 3.4 & 0 & 0.58 \\
Mar. 03 & 3.6 & 3.6 & $-\mathbf{3 . 5}$ & 1.00 \\
Mean DS & $\mathbf{7 . 1}$ & $\mathbf{3 . 6}$ & $\mathbf{2 . 5}$ & $\mathbf{0 . 6 1}$ \\
SE & $\mathbf{4 . 1}$ & $\mathbf{1 . 7}$ & $\mathbf{0 . 1 9}$ \\
\hline
\end{tabular}

\begin{tabular}{|c|c|c|c|c|}
\hline \multicolumn{5}{|c|}{ Upstream reach } \\
\hline Jul. 02 & 8.0 & -1.2 & -9.2 & -0.15 \\
\hline Aug. 02 & 5.0 & 1.2 & -3.8 & 0.24 \\
\hline Jun. 03 & 2.4 & 0 & -2.4 & 0.00 \\
\hline Mean US & 5.1 & 0.0 & -5.1 & 0.03 \\
\hline SE & 1.6 & 0.7 & 2.1 & 0.11 \\
\hline \multicolumn{5}{|c|}{ Downstream reach } \\
\hline Jul. 02 & 14.0 & 0 & -14 & 0.00 \\
\hline Aug. 02 & 14.0 & 4.0 & -10.0 & 0.28 \\
\hline Jun. 03 & 84.8 & 13.8 & -71.0 & 0.16 \\
\hline Mean DS & 37.6 & 5.9 & -12.0 & 0.15 \\
\hline SE & 23.6 & 4.1 & 2.0 & 0.14 \\
\hline
\end{tabular}

and the $\mathrm{P} / \mathrm{R}$ ratio do not show significant seasonal variations.

\section{Invertebrates}

Invertebrate communities were characterized using density and biomass at community and functional feeding group scales. FFG density and biomass patterns differed for the various sections of river (Fig. 4). FFG densities were significantly greater on the DS sub-reach at Montégut, while opposite variations are observed for the Lézat site (ANOVA, reach effects for density and biomass, $P$ from 0.001 to 0.05 , Table 4 ). In contrast, no significant biomass differences between US and DS sub-reaches occurred at Montégut. For biomass a reach effect was observed at Lézat, as a result of the extremely low DS invertebrate densities for shredders, scrapers and filtering collectors.

Invertebrate distributions within the different functional feeding groups differed at both sites (ANOVA, FFG effect for density/biomass, $P<0.001$ ). The FFG gathering collectors dominated in all reaches, with large densities and biomass for Chironomidae. The second group in order of dominance for densities and biomass were predators. Combined effects (interactions) between FFG and reach position were not significant, emphasizing a relative longitudinal constancy of the invertebrate community parameters at both sites.

\section{Biofilm biomass}

The spatial distribution of biofilm ash-free dry mass $\left(\mathrm{mg} . \mathrm{m}^{-2}\right)$ was explored for each sub-reach. Biofilm biomass was more abundant at Montégut (mean 15.34 g.m ${ }^{-2}$ US and 137.33 g.m ${ }^{-2}$ DS) than at Lézat site $\left(14.90\right.$ g.m ${ }^{-2}$ US and 9.94 g.m ${ }^{-2}$ DS). Also, reach effects occurred at Montégut with DS biofilm higher than US.

\section{Discussion}

Nitrogen mainly occurred present in the waters of the Lèze River as dissolved forms. Nitrate increased between 

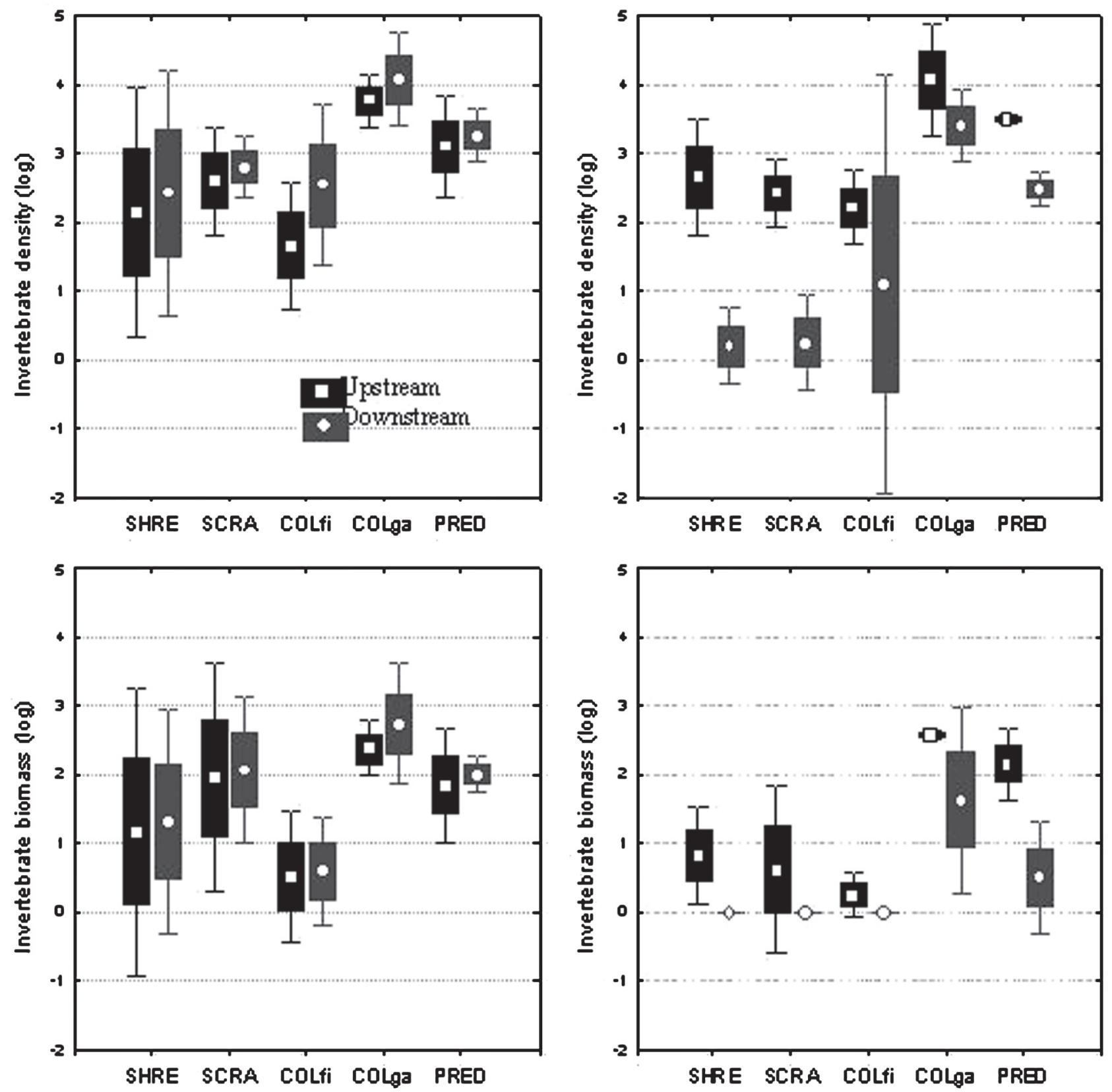

Fig. 4. Characteristics of the invertebrate assemblages at the two experimental sites. A: Montégut site, B: Lézat site. Total density and biomass per functional feeding group for upstream and downstream sub-reaches (means, standard deviations, 95\% confidence intervals). SCRA $=$ scrapers, COLfi $=$ filtering collectors, $\mathrm{SHRE}=$ shredders, COLga $=$ gathering collectors, $\mathrm{PRE}=$ predators

the upstream and downstream parts of the watershed owing to enrichment by lateral contributions. This supports the results of a nitrogen export survey done on the Garonne basin by Probst (1985). The author demonstrates that a strong correlation exists between the contributions of fertilizers and the flux of nitrogen on the scale of the basin. Patterns evolution of ammonium concentrations follows an inverse gradient to that observed for the other nitrogenous forms. The maximal concentrations of $\mathrm{NH}_{4}^{+}-\mathrm{N}$ were measured in the upstream part of the watershed at Mondély dam $\left(0.73 \mathrm{mg} . \mathrm{L}^{-1}\right.$ on average) owing to the origin of the anaerobic water which came from the hypolimnion of the dam. In the upstream part of the basin, organic forms of nitrogen represent more than $50 \%$ of the TN. In the downstream part of the basin, nitrate represent the dominant fraction of $\mathrm{TN}$. The increase in nitrate concentration in the river is due to lateral groundwater contributions. On the scale of the study site, the ratio between $\mathrm{NH}_{4}^{+}-\mathrm{N}$ flux from the WWTP and mean $\mathrm{NH}_{4}^{+}-\mathrm{N}$ flux circulating in the river were similar in the two study sites at around 0.08 . For N-org fluxes, the ratio was not similar, no $\mathrm{N}$-org fluxes entered the river at Montégut while at Lézat the ratio was around 0.16.

Phosphorus was essentially present in organic form $(90 \%)$, similar to the proportions reported in other studies (Broberg and Persson, 1988; Turner et al., 2003). 
Table 4. Probabilities of the effect of invertebrate assemblages composition (FFG) and sub-reach position (US - DS) on total density and biomass in the two experimental sites (Multi-factor ANOVA). In bold, probabilities that indicate a significant effect.

\begin{tabular}{|c|c|c|c|}
\hline & \multirow[b]{2}{*}{ Factor } & \multirow{2}{*}{$\frac{\text { Density }}{P}$} & \multirow{2}{*}{$\frac{\text { Biomass }}{P}$} \\
\hline & & & \\
\hline \multirow{3}{*}{ Montégut site } & FFG & $<0.001$ & $<0.001$ \\
\hline & Reach & $<0.05$ & 0.3683 \\
\hline & $\mathrm{FFG} *$ Reach & 0.6667 & 0.9923 \\
\hline \multirow[t]{3}{*}{ Lézat site } & $\mathrm{FFG}$ & $<0.001$ & $<0.001$ \\
\hline & Reach & $<0.001$ & $<0.001$ \\
\hline & FFG $*$ Reach & 0.187 & 0.156 \\
\hline
\end{tabular}

Orthophosphates represented less than $1 \%$ of the total phosphorus. In river systems, dissolved organic forms of phosphorus are readily available to the organisms (Broberg and Persson, 1988). TP and TDP increased in the downstream part of the basin where anthropogenic effects were stronger. Lateral contributions were rich in organic and mineral phosphorus (Dorioz and Fehri, 1994). Once in the river, these phosphorus compounds tend to desorb and dissolve (Boström et al., 1982). These authors reported a parallel between the increase of the fraction dissolved and the increase of the total phosphorus content. Downstream in the basin, this phenomenon is amplified by the punctual input of orthophosphates by the WWTP.

Nutrient uptake did not show differences between upstream and downstream sub-reaches for any of the elements or between sites except for $\mathrm{P}_{-} \mathrm{PO}_{4}^{-3}$ at the Montégut site. Data on nutrient removal indicated that nitrogen demand always exceeded phosphorus demand. The $\mathrm{NH}_{4}^{+}-\mathrm{N}$ form were always removed more efficiently from the water column than the $\mathrm{NO}_{3}^{-}-\mathrm{N}$ form. $\mathrm{NH}_{4}^{+}-\mathrm{N}$ removal can be explained by the preference of the fungi, bacteria and algae for this from of nitrogen (Martí and Sabater, 1996; Haggard et al., 2001). Negative values of nutrient retention parameters indicate production in the reach. These negative values indicate that the sources exceed the uptake capacity, as observed in other Mediterranean streams (Martí et al., 2004). The additional sources could be (i) lateral and vertical subsurface inputs along the reach (Dent and Grimm, 1999), (ii) a dominance of in-stream release processes (e.g., from precipitationdissolution, mineralization of organic matter, and nitrification).

Metabolism at the Lézat and Montégut sites was dominated by respiration levels generally higher than primary production. This is in agreement with previous metabolism estimations in low order streams such as the Walker Branch stream in a forested watershed (Tennessee, USA) described by Marzolf et al. (1994). It should be noted that the high value of $\mathrm{R}$ rate measured at the Lézat site on $05 / 05 / 03$ in the downstream sub-reach (84.8 $\mathrm{g} \mathrm{O}_{2} \cdot \mathrm{m}^{-2} \cdot \mathrm{d}^{-1}$ ), was probably influenced by the punctual occurrence of organic crop fertilisation some days before the metabolism experiment.
In a similar work, Ruggiero et al. (2006) show that WWTP effluent caused an increase of organic matter due to a higher heterotrophic microbial biomass and higher community respiration. Values of respiration rates in downstream sub-reaches of both sites ranged from 1.2 and $84.8 \mathrm{~g} \mathrm{O}_{2} \cdot \mathrm{m}^{-2} \cdot \mathrm{d}^{-1}$, and are similar to the range of oxygen demand by fungal biofilm measured by Hickey (1988) in an in situ benthic chamber in a stream influenced by human altered water inputs ( 3 to $70 \mathrm{~g} \mathrm{O}_{2} \cdot \mathrm{m}^{-2} \cdot \mathrm{d}^{-1}$ ). Daily respiration rates, did not change in downstream subreaches affected by the WWTP input at the Montégut site, so the punctual input of $\mathrm{N}, \mathrm{P}$ and fine particular organic matter does not seem to produce an effect on respiration. In the Montégut site an increase in the biofilm biomass in the river was explained by the amount of organic matter introduced from cattle. At the Lézat site, mean daily respiration values showed a significant increase in the downstream sub-reach. Variations in the respiration rates at this site indicated that non-point-source $\mathrm{N}$ inputs influenced the measurements. The respiration rate was also largely controlled by water exchange with the hyporheic zones (Wang et al., 2003), and it may be interesting to take this geomorphological parameter into account to explain the results obtained. Nutrient $(\mathrm{P}$ and $\mathrm{N}$ ) seems to play a minor role in inter-site variations of epilithic biofilm biomass as shown by Izagirre and Elosegui (2005) in a stream of North Spain.

GPP rates did not change between upstream and downstream sub-reaches or between sites. Low values of GPP rates were related to autotrophic development of epilithic biofilm on the same reach. During most of the period of metabolism measurement, this biofilm was lacking or remained very scarce in the reaches studied. Biofilm biomass is negatively influenced by invertebrate grazing, more particularly by scrapers which are generally more abundant in downstream reaches. GPP varies significantly with season, owing primarily to leaf shading effects by the riparian forest, lowering the level of sunlight reaching the stream bed. This canopy effect only influences the phototrophic community (Marzolf et al., 1994; Guasch et al., 1998): in spring the GPP is maximal due to the lack of canopy and strong algal development, in late spring GPP begins to decrease as the leaves appear. In autumn, GPP is enhanced when leaf fall begins. It can be noted that during autumn, the $\mathrm{R}$ rate and shredder FFG should also increase due to leaf litter reaching the stream (Marzolf et al., 1994).

Odum (1956) and Billen and Garnier (1999) suggested characterising the trophic status of streams according to the $P / R$ ratio. Since this ratio is lower than 1 in more than 13 cases out of 16 , the Lézat and Montégut sites function as heterotrophic ecosystems during most of the year. All Lézat measurements were performed from May to August and indicate this type of functioning during this period. At the Montégut site three of the $\mathrm{P} / \mathrm{R}$ ratios were close to 1 , indicating a balance between heterotrophy and autotrophy. This balanced status occurred in spring on the upstream sub-reach and in spring and autumn on the downstream sub-reach due to increased GPP at this time. 
Table 5. Functional feeding groups ratios according to Merritt and Cummins (1996) classification. SCRA $=$ scrapers, COLfi $=$ filtering collectors, SHRE $=$ shredders, COLga = gathering collectors, PRE $=$ predators. (a) represents SCRA/(SHRE + COLga) ratio, (b) SHRE/COLga, (c) COLfi/COLga, (d) (SCRA + COLfi)/ (SHRE + COLga), (e) PRE/(all others).

\begin{tabular}{lcccccc}
\hline & & (a) & (b) & (c) & (d) & (e) \\
\hline Montégut & & & & & & \\
\hline Density & US & 0.11 & 0.07 & 0.02 & 0.13 & 0.18 \\
& DS & 0.06 & 0.04 & 0.09 & 0.16 & 0.15 \\
Biomass & US & 1.01 & 0.22 & 0.02 & 1.04 & 0.13 \\
& DS & 0.31 & 0.05 & 0.01 & 0.32 & 0.15 \\
\hline Lézat & & & & & & \\
\hline Density & US & 0.03 & 0.08 & 0.01 & 0.05 & 0.20 \\
& DS & 0.00 & 0.00 & 0.02 & 0.02 & 0.12 \\
Biomass & US & 0.01 & 0.02 & 0.00 & 0.02 & 0.28 \\
& DS & 0.00 & 0.00 & 0.00 & 0.00 & 0.04 \\
\hline
\end{tabular}

Exploration of the functional characteristics of the experimental sites reveals that, on a local scale, WWTP inputs had no effect on respiration or primary production. Non-local pollution sources added to local nutrient sources appeared more efficient at increasing respiration. Primary production is explained by a seasonal variation of GPP that overlapped the effect of sites location and of WWTP. WWTP and site location influenced biofilm biomass. $\mathrm{P} / \mathrm{R}<<1$ everywhere indicates heterotrophy at both sites and Lézat, located lower in the watershed, is more heterotrophic than Montégut.

A functional feeding group is defined as a group of species that produce similar effects on key functional processes of the ecosystem (Chapin et al., 1998). The composition of the benthic invertebrate community is largely dependent on the habitat characteristics and trophic conditions of the ecosystem (Miserendino, 2007). Merritt and Cummins (1996) provided a classification of streams according to FFG ratios. Density or biomass may be used to calculate these ratios. In the present studies, the two descriptors are summarized in Table 5. The ratio scrapers/(shredders + filtering collectors) lower than 0.75 in all the communities at Montégut and Lézat sites confirms the heterotrophic characteristics of this stream, with a mobile substratum (((scrapers + filtering collectors $) /($ shredders + gathering collectors $))<0.5$ ). Prey and predator ratios on all downstream sub-reaches were lower than 0.15 indicating that the communities sampled are correctly balanced between prey and predators downstream of the WWTP. This balance informs us that the conclusions reached from the FFG ratio are representative of the trophic conditions of the ecosystem studied. Ratios of shredders to collectors lower than 0.25 on all reaches indicate that organic mater as a trophic source of these communities is dominated by the fine fraction. Since the ratio (scrapers + filtering collectors)/(shredders + gathering collectors) is lower than 0.5 this fine particulate organic matter occurs predominantly in the sediment compartment. The latter ratio also suggests that variation of the density and biomass of the communities under the effects of the WWTP do not result from quantitative changes in the particulate organic matter supplies. These variations are more realistically caused by differences in the qualitative composition of the trophic resources, or differences in the nutrient loads of the water.

\section{Conclusions}

To sum up, the results at the local scale indicate that heterotrophy in the Lèze river is created by $\mathrm{N}$ and $\mathrm{P}$ with two distinct point sources for P (urban area and WWTP) and with non-point sources for $\mathrm{N}$ (agricultural zones). WWTP do not affect uptake rates (except for $\mathrm{P}$ at the Montégut site), respiration and primary production of the ecosystem, but local inputs from WWTP increase benthic density and biomass (specially gathering collectors) with fine particulate organic matter arriving at the site with high nutrient levels. Functional feeding group ratios confirm the heterotrophic character of the Lèze river with a dominance of fine particulate organic matter as a trophic source for the invertebrate community. Absence of metabolism variations does not enable relationships with uptake rates to be established. For macro-invertebrate interventions on uptake rates, the relation with density, diversity and gathering collectors should be checked at the inter-site scale. This study demonstrated that, in a highly disturbed watershed, no significant effects of nutrient pollution types (local/non local) exist on in-stream uptake rates. However, these pollution types affect metabolisms and invertebrates assemblages differently. In these conditions the present data set does not indicate relationships between the investigated functional processes, uptakes rates, metabolisms and invertebrate feeding groups composition. This absence of relations is attributed to the uptake rate variance between sub-reaches and sites which indicates that other functional factors may interfere with nutrient retention capacities, like geomorphological features and/or discharge rates.

Acknowledgements. This study was part of the STREAMES Project (a FP5 European Union funded projects, EKV1-CT2000-00081): Human effects on nutrient cycling in fluvial ecosystems: The development of an Expert System to assess stream water quality management at reach scale. We are grateful to Mr. Peyrat (SATESE) for WWTP nitrogen fluxe data and the French Regional Environmental Agency for discharge data.

\section{References}

Billen G. and Garnier J., 1999. Nitrogen transfers through the Seine drainage network: a budget based on the application of the 'Riverstrahler' model. Hydrobiologia, 410, 139-150.

Boström B., Jansson M. and Forsberg C., 1982. Phosphorus release from lake sediments. Arch. Hydrobiol. Beih. Ergebn. Limnol., 18, 5-59. 
Broberg O. and Persson G., 1988. Particulate and dissolved phosphorus forms in freshwater: composition and analysis. Hydrobiologia, 170, 61-90.

Butturini A. and Sabater F., 1998. Ammonium and phosphate retention in a Mediterranean stream: hydrological versus temperature control. Can. J. Fish. Aquat. Sci., 55, 1938-1945.

Chapin F.S., Sala O.E., Burke I.C., Grime J.P., Hooper D.U., Lauenroth W.K., Lombard A., Mooney H.A., Mosier A.R., Naeem S., Pacala S.W., Roy J., Steffen W.L. and Tilman D., 1998. Ecosystem consequences of changing biodiversity: experimental evidence and a research agenda for the future. Bioscience, 48, 45-52.

Chapra S.C., Canale R.P. and Amy G.L., 1997. Empirical models for disinfection by-products in lakes and reservoirs. J. Environ. Engineering-ASCE, 123, 714-715.

Crenshaw C.L., Valett H.M. and Webster J.R., 2002. Effects of augmentation of coarse particulate organic matter on metabolism and nutrient retention in hyporheic sediments. Freshwat. Biol., 47, 1820-1831.

Dent C.L. and Grimm N.B., 1999. Spatial heterogeneity of stream water nutrient concentrations over successional time. Ecology, 80, 2283-2298.

Dorioz J.M. and Ferhi A., 1994. Non-point pollution and management of agricultural areas: phosphorus and nitrogen transfer in an agricultural watershed. Wat. Res., 28, 395-410.

Fisher S.G., Grimm N.B., Marti E., Holmes R.M. and Jones J.B., 1998. Material spiraling in stream corridors: A telescoping ecosystem model. Ecosystems, 1, 19-34.

Gordon N.D., McMahon T.A. and Finlayson B.L., 1994. Stream hydrology, John Wiley \& Sons, West Sussex, England, 526 p.

Guasch H., Armengol J., Martí E. and Sabater S., 1998. Diurnal variation in dissolved oxygen and carbon dioxide in two loworder streams. Wat. Res., 32, 1067-1074.

Gücker B. and Pusch M.T., 2006. Regulation of nutrient uptake in eutrophic lowland streams. Limnol. Oceanogr., 51, 14431453.

Haggard B.E., Storm D.E. and Stanley E.H., 2001. Effects of a point source input on stream nutrient retention. J. Am. Water Resour. Assoc., 37, 1291-1299.

Haggard B.E., Stanley E.H. and Storm D.E., 2005. Nutrient retention in a point-source-enriched stream. J. N. Am. Benthol. Soc., 24, 29-47.

Hickey C.W., 1988. River oxygen uptake and respiratory decay of sewage fungus biofilms. Wat. Res., 22, 1375-1380.

House W.A., Leach D.V. and Armitage P.D., 2001. Study of dissolved silicon and nitrate dynamics in a freshwater stream. Wat. Res., 35, 2749-2757.

Isaacs W.P. and Gaudy A.F., Jr., 1968. Atmospheric oxygenation in a simulated stream. J. Sanit. Eng. Div., Proc. ASCE, 94, 319-344.

Izagirre O. and Elosegui A., 2005. Environmental control of seasonal and inter-annual variations of periphytic biomass in a North Iberian stream. Ann. Limnol. - Int. J. Lim., 41, 35-46.

Lefebvre S., Marmonier P. and Peiry J.L., 2006. Nitrogen dynamics in rural streams: differences between geomorphologic units. Ann. Limnol. - Int. J. Lim., 42, 43-53.

Martí E. and Sabater F., 1996. High variability in temporal and spatial nutrient retention in Mediterranean streams. Ecology, 77, 854-869.
Martí E., Aumatell J., Godé L., Poch M. and Sabater F., 2004. Nutrient retention efficiency in streams receiving inputs from wastewater treatment plants. J. Environ. Qual., 33, 285-293.

Marzolf E.R., Mulholland P.J. and Steiman A.D., 1994. Improvements to diurnal upstream-downstream dissolved oxygen change technique for determining whole stream metabolism in small streams. Can. J. Fish. Aquat. Sci., 51, 1591-1599.

Merrit R.W. and Cummins K.W., 1984. An introduction to the aquatic insects of North America, 722 p.

Merrit R.W. and Cummins K.W., 1996. Methods in stream ecology, Academic Press, London.

Merseburger G.C., Martí E. and Sabater F., 2005. Net changes in nutrient concentrations below a point source input in two streams draining catchments with contrasting land uses. Sci. Total Environ., 347, 217-229.

Miserendino M.L., 2007. Macroinvertebrate functional organization and water quality in a large arid river from Patagonia (Argentina). Ann. Limnol. - Int. J. Lim., 43, 133-145.

Mulholland P.J., Fellows C.S., Tank J.L., Grimm N.B., Webster J.R., Hamilton S.K., Martí E., Ashkenas L., Bowden W.B., Dodds W.K., McDowell W.H., Paul M.J. and Peterson B.J., 2001. Inter-biome comparison of factors controlling stream metabolism. Freshwat. Biol., 46, 1503-1517.

Newbold J.D., Elwood J.W., O’Neill R.V. and Van Winkle W., 1981. Measuring nutrient spiralling in streams. Can. J. Fish. Aquat. Sci., 38, 860-863.

O'Connor D.J. and Dobbins W.E., 1958. Mechanism of reaeration in natural streams. Trans. Amer. Soc. Chem. Eng., 123, 641-684.

Odum H.T., 1956. Primary production in flowing water. Limnol. Oceanogr., 1, 102-117.

Owens M., Edwards R.W. and Gibbs J.W., 1964. Some reaeration studies in stream. Int. J. Air. Wat. Poll., 8, 469-486.

Paul M.J. and Meyer J.L., 2001. Streams in the urban landscape. Ann. Rev. Ecol. Syst., 32, 333-365.

Pennak R.W., 1978. Fresh-water invertebrates of the United States, Wiley-Interscience, $788 \mathrm{p}$.

Prenda J. and Gallardo-Mayenco A., 1996. Self-purification, temporal variability and the macroinvertebrate community in small lowland Mediterranean streams receiving crude domestic sewage effluents. Arch. Hydrobiol., 136, 159-170.

Probst J.L., 1985. Nitrogen and phosphorus exportation in the Garonne Basin (France). J. Hydrol., 76, 281-305.

Puig M.A., 1999. Els macroinvertebrats dels rius Catalans, Guia illustrada, $245 \mathrm{p}$.

Rathbun R.E., Stephens D.W., Schultz D.J. and Tai D.Y., 1978. Laboratory studies of gas tracer for reaeration. Proc. ASCE, 104, 215-219.

Rodier J., 1996. L'analyse de l'eau : eaux naturelles, eaux résiduaires, eau de mer, Dunod, Paris, 1383 p.

Ruggiero A., Solimini A.G. and Carchini G., 2006. Effects of a waste water treatment plant on organic matter dynamics and ecosystem functioning in a Mediterranean stream. Ann. Limnol. - Int. J. Lim., 42, 97-107.

Stream Solute Workshop, 1990. Concepts and methods for assessing solute dynamics in stream ecosystems. J. N. Amer. Benthol. Soc., 9, 95-119.

Tachet H., Richoux P., Bournaud M. and Usseglio-Polatera P., 2000. Invertébrés d'eau douce : systématique, biologie, écologie, CNRS Éditions, 587 p. 
Thyssen N., Erlandsen M. and Jeppensen E., 1987. Reaeration oxygen in shallow macrophyte-rich streams. Int. Rev. Ges. Hydrobiol., 72, 405-429.

Turlan T., Birgand F. and Marmonier P., 2007. Comparative use of field and laboratory mesocosms for in-stream nitrate uptake measurement. Ann. Limnol. - Int. J. Lim., 43, 41-51.

Turner B.L., Baxter R. and Whitton B.A., 2003. Nitrogen and phosphorus in soil solution and drainage streams in Upper Teesdale, northern England: implication of organic compounds for biological nutrient limitation. Sci. Tot. Environ., 314-316, 153-170.

Valett H.M., Dahm C.N., Campana M.E., Morrice J.A., Baker M.A. and Fellows C.S., 1997. Hydrologic influences on groundwater - surface water ecotones: Heterogeneity in nutrient composition and retention. J. N. Amer. Benthol. Soc., 16, 239-247.

Vitousek P.M., Aber J.D., Howarth R.W., Likens G.E., Matson P.A., Schindler D.W., Schlesinger W.H. and Tilman D.G., 1997. Human alteration of the global nitrogen cycle: Sources and consequences. Ecol. Appl., 7, 737-750.

Wang H., Hondzo M., Xu C., Poole V. and Spacie A., 2003. Dissolved oxygen dynamics of streams draining an urbanized and agricultural catchment. Ecol. Model., 160, 145-161.

Young R.G. and Huryn A.D., 1998. Comment: Improvements to diurnal upstream-downstream dissolved oxygen change technique for determining whole stream metabolism in small streams. Can. J. Fish. Aquat. Sci., 55, 1784-1785. 